\title{
Molecular Characterization of Gut Bacterial Flora of Honeybee (Apis Mellifera Adansonii) From Some Selected Apiaries in Ogun State, Nigeria
}

\section{OLADIPUPO-ALADE, EO; LAWAL, OA; OYEWO, IO; ODIAKA, IE; HAASTRUP, NO; OYEDELE, MD; GANIYU, OA}

\author{
Forestry Research Institute of Nigeria, Jericho Hill Ibadan, Nigeria \\ *Corresponding Author Email: haastrup.no@frin.gov.ng; Tel: 08065567335
}

\begin{abstract}
Research related to physiology and pathology of honey bees in particular Apis mellifera adansonii has attracted a lot of attention. The present study is aimed to determine honeybee (Apis mellifera adansonii) gut microbiome from Apiary in Olabisi Onabanjo University and Osoba Avenue Odo-Epo, Odogbolu Local Government. Twenty (20) honeybees workers (A. mellifera) were collected into a small vile containing sugar powder from the apiary located in OOU and Osoba Avenue at Odo-Epo during rainy season in July and transported to Zoology and Environmental Biology laboratory in $\mathrm{OOU}$ and kept in ice-cubes $\left(-5^{\circ} \mathrm{C}\right)$ till daybreak. Standard microbiological analysis for isolation of bacteria was used, adopting Clinical Laboratory Standard Institute procedures. The phylogenetic analyses based on the 16S rDNA gene were further used to characterize the organism in order to establish relationships among them. The results showed microbiota of the studied samples includes; Cedeca davisae, Cronobacter dublinensis, Enterobacter aerogenes, Kluyvera cryocrescens, Klebsiella oxytoca, Providencia vermicola, Salmonella enteric, Providencia alcalifaciens, Serratia nematodiphila, Pseudomonas plecoqlossicida, Klebsiella michiganensis, Serratia marcenscens, Pseudomonas aeruginosa, Escherichia coli, Aeromonas hydrophila and Enterobacter asburiae. Klebsiella spp. was more abundant and prominent in the digestive guts of honeybee workers both in OOU and Osoba Avenue, Odo Epo. The result of the percentage identity and closest accession of the isolates revealed that, Enterobacter aerogenes had the closest accession number and with highest percentage identity of (99\%). The findings from this study showed that microbiota component communities of A. mellifera adansonii in OOU were composed of more Gram-negative bacteria than Gram-positive bacteria in Odo Epo.
\end{abstract}

DOI: https://dx.doi.org/10.4314/jasem.v25i4.18

Copyright: Copyright $\odot 2021$ Oladipupo-Alade et al. This is an open access article distributed under the Creative Commons Attribution License (CCL), which permits unrestricted use, distribution, and reproduction in any medium, provided the original work is properly cited.

Dates: Received: 14 February 2021; Revised: 26 March 2021; Accepted: 12 April 2021

Keywords: Honeybee, Gut, Microbiome, Apiary

Honey is a sweet food created by bees using nectar from flowers. It is composed of $17 \%$ water and $82 \%$ carbohydrates; it has low content of fat, dietary fiber, and protein. A mixture of sugars and other carbohydrates, honey is mainly fructose (about 38\%) and glucose (about 32\%), with remaining sugars including maltose, sucrose, and other complex carbohydrates. Honey also contains minerals, vitamins and metals. Compared to other bee species, honey bees have been reported to increase the yield in animal pollinated crops which account for $35 \%$ of the global food production (Guo et al., 2015). Furthermore, research related to physiology and pathology of honey bees in particular Apis mellifera adansonii has attracted a lot of attention (Muli et al., 2014). Muli et al., (2014) reported that A. mellifera adansonii (honeybee) is about the most common that has been given due attention in Nigeria probably because of its beneficial attributes as a natural agent of pollination and as the most important of all insect pollinators.
Numerous causes of severe honey bee colony losses have been proposed, including pesticides toxicity, poor nutrition and genetic diversity. This therefore called for a deeper understanding of both symbiotic and pathogenic microbial interactions, particularly as they relate to food storage and the pollination environment. A high load of parasites and microbial pathogens, especially bacteria strongly connected with the disappearing of bee population. Therefore, characterization of bee gut microbiome can provide valuable insight of parasites and bacterial pathogens. Anatomically, the foregut is the honeybee's social/nutritional interface. This portion of the alimentary tract is essentially an inflatable storage bag used to transport nectar from the flower to the hive, and selectively pass pollen into the midgut. More generally, the crop represents the microbial intersection of food sharing, food storage and the pollination environment. At the flower, pollen foragers use their forelegs and tongue to gain access to 
nectar and pollen. Pollen accumulated on the head and body hairs is consolidated using the forelegs, mixed with liquid sugars from the crop, and this sticky mixture is packed into hind leg pollen baskets called corbiculae. Once returned to the hive, corbicular pollen pellets are packed tightly into wax cells and become beebread, a nutrient dense mixture of pollen, honey and various microbes. Bacteriological analysis along with molecular techniques based on 16S rRNA sequences precisely characterize insects gut bacterial flora. The composition of bacterial assemblage in the digestive tract of honey bee A. mellifera is relatively simple compared with other gut-associated communities (Li et al., 2015). A distinctive set of bacteria including Firmicutes, Actinobacteria, $\alpha$ - and $\gamma$-proteobacteria found in the honey bee alimentary canal has been assessed by using Sanger as well as next generation sequencing techniques (Engel et al., 2016).

Due to the high density of individuals within colonies, sharing of food and other resources and the coexistence of colony members from multiple generations, social insects provide unique resources for studying microbial symbionts. These bacterial communities vary immensely in total size, composition, location and functions within the individual parts of the gut. The adult honeybee hosts up to 109 bacterial cells, consisting of 8 abundant phylotypes making up to $95 \%$ of the total bacteria that appear to be specific to social bees. The maintenance of this stable and distinct microbial community depends on the nutrition and social lifestyle of these insects (Engel et al., 2016), environment and ontogenetic stage. Gut commensal bacteria, also known as microbiota, are microorganisms that colonize the digestive tracts of different animal species including insects. Some of the microbiota are opportunist species whose quantity and composition vary with food sources, season and other environmental factors (Baffoni et al., 2016). Metagenomic analysis has provided adequate knowledge about the physiology, immunity, behavior, growth, development, and survivor of the honeybee. Metagenomic analysis can be applied in the discovery of unknown pathogens and can also be used to determine the health of honeybee. In the light of the aforementioned, the present study is aimed to determine honeybee (Apis mellifera adansonii) gut microbiome from Apiary in Olabisi Onabanjo University and 4 Osoba Avenue, Odo-Epo.

\section{MATERIALS AND METHODS}

The study was carried out in some selected apiaries located in Ago-Iwoye in Ijebu North Local Government Area and 4 Osoba Avenue at Odoepo in Odogbolu Local Government Area, Ogun State, Nigeria. Ago Iwoye has a latititude of $6.9424^{\circ} \mathrm{N}$ and a longitude of $3.9216^{\circ} \mathrm{E}$ respectively while Odo Epo has a latitude of $6.7888^{\circ} \mathrm{N}$ and a longitude of $3.9684^{\circ} \mathrm{E}$.

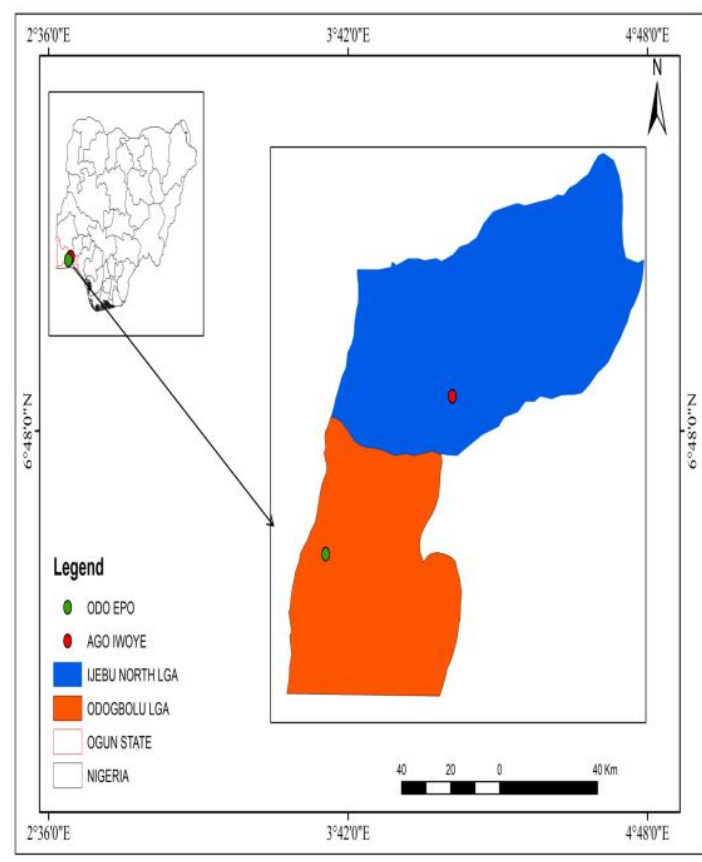

Fig 1: The study area (Source: Map Data, 2017)

Glasswares and Equipment Used: The materials used include: Test tubes, Petri dishes, swab stick, dissecting kit, wax dish, inoculating loop, media, spatula, hand gloves, ethanol, aluminum foil papers, distilled water, beakers, hot air oven, incubator, autoclave, measuring cylinders, glass slides, cover slips, weighing balance, cotton wool, microscope, funnel, MarConkey bottles and pipette.

Media and Chemicals Used: Eosine Methylene Blue agar (EMB), Salmonella Shigella agar, Simmon's Citrate agar, Ethanol and peptone water, Gram staining reagents.

Sterilization of Glassware: All Glass-wares used were properly washed and drain-dried. Media were prepared according to the manufacturer instruction under aseptic condition.

Sample Collection of Honey Bee: In order to study the cultivable honey bee gut bacteria, 20 honeybees of ( $A$. mellifera) unknown age were collected each from the apiary located in OOU and Odo Epo. Honey bee samples were collected early in the morning before sun rise. After collection, life honey bees were transported to Zoology and Environmental Biology Laboratory in OOU in a labeled vial containing sugar powder and kept at room temperature till daybreak. The collection of honeybee samples was done between July and October 2018 during the raining season. Before dissection, the honeybees were rinsed in $95 \%$ ethanol and complete alimentary canals of the bees 
were aseptically dissected by clipping the stinger with sterile forceps. The insect abdomen was open up using a sterile dissecting scissors; the guts content was taken using a sterilized swab stick.

Molecular Characterization of Isolated Bacteria from Water (Isolation of Template DNA): The Bacterial template DNA was extracted at International Institute of Tropical Agriculture (IITA) Ibadan. The procedures for the isolation are illustrated as follows. Fifty to one hundred (50-100mg) (wet weight) bacterial cells that have been re-suspended in up to $200 \mu$ l of water or isotonic buffer (e.g., PBS).These were secured in a bead fitted with $2 \mathrm{ml}$ tube holder assembly and process at maximum speed for $\geq 5$ minutes. The mixture were centrifuged in a microcentirifuge at $>10,000 \mathrm{x} g$ for 1 minute, after which the supernatant $(400 \mu \mathrm{l})$ were then transferred up to a Zymo-Spin ${ }^{\mathrm{TM}}$ IV Spin Filter (orange top) in a Collection Tube and centrifuge at $7,000 \mathrm{x} g$ for 1 minute. To the filtrate in the collection tube was added 1,200 $\mu$ of Bacterial DNA Binding Buffer, after which $800 \mu$ of the mixture from Step 5 was transferred to a Zymo-Spin ${ }^{\mathrm{TM}}$ IIC Columnin a Collection Tube and centrifuge at $10,000 \mathrm{x} \mathrm{g}$ for 1 minute. The flow through from the Collection tube were discarded and repeated. An additional $200 \mu \mathrm{l}$ DNA Pre-Wash Buffer was made to the Zymo-Spin ${ }^{\mathrm{TM}}$ IIC Column in new Collection Tube and centrifuge at $10,000 \times \mathrm{g}$ for 1 minute. Another $500 \mu \mathrm{lBacterial} \mathrm{DNA}$ Wash Buffer was added to the Zymo-Spin ${ }^{\mathrm{TM}}$ IIC Column and centrifuge at 10,000 x g for 1 minute. The Zymo-Spin ${ }^{\mathrm{TM}}$ IIC Column was transferred to a clean $1.5 \mathrm{ml}$ micro centrifuge tube and 100ul (35 $\mu \mathrm{l}$ minimum) DNA Elution Buffer was added directly to the column matrix. Centrifuge at $10,000 \mathrm{x} \mathrm{g}$ for 30 seconds to elude the DNA. DNA obtained was now suitable for PCR and other downstream applications.
Polymerase Chain Reaction Amplification: The PCR Amplification was carried out at International Institute of Tropical Agriculture (IITA) Ibadan. The samples were arranged from the first to the twelve just after the DNA ladder. The samples ID are included in the Nano drop readings. The PCR cocktail mix consists of $1.0 \mu \mathrm{l}$ of 10x PCR buffer. $1 \mu$ lof $25 \mathrm{mM} \mathrm{m}_{\mathrm{g}} \mathrm{cl}_{2}$, $1 \mathrm{ul}$ each of forward primer16SF: GTGCCAGCAGCCGCGCTAA and reverse primer 16SR: AGACCCGGGAACGTATTCAC 1ul of DMSO, $0.8 \mathrm{ul}$ of $2.5 \mathrm{MMDNTP}_{\mathrm{S}}, 0.1 \mu \mathrm{l}$ of $5 \mu \mathrm{l}$ TaqDNA polymerase and $2.0 \mathrm{ul}$ of $10 \mathrm{ng} / \mu \mathrm{l}$ DNA. The total reaction volume was made up of $10 \mu \mathrm{l}$ using $3.1 \mathrm{ul}$ nuclease free water. Below are the PCR cycling parameters; Initial denaturation $94^{\circ} \mathrm{C}$ for 30 seconds, annealing at $56^{\circ} \mathrm{C}$ for 30 seconds and elongation at $72^{\circ} \mathrm{C}$ for 45 seconds followed by final elongation step at $72^{\circ} \mathrm{C}$ for 7 minutes and hold temperature at $10^{\circ} \mathrm{C}$ forever. Amplified Fragment was visualized on safe view stained 1.5\% Agarose Electrophoresis Gels. This protocol is also attached. The DNA was subjected to the following cocktail mix and condition for the PCR.

Table 1: Coctail mix

\begin{tabular}{|c|c|}
\hline Content & Quantity $(\mu 1)$ \\
\hline $10 \times$ PCR buffer & 1.0 \\
\hline $25 \mathrm{mM} \mathrm{MgCl}{ }_{2}$ & 1.0 \\
\hline $5 \mathrm{pMol}$ forward primer & 0.5 \\
\hline $5 \mathrm{pMol}$ reverse primer & 0.5 \\
\hline Dimethyl Sulfoxide (DMSO) & 1.0 \\
\hline 2.5Mm DNTPs & 0.8 \\
\hline $\operatorname{Taq} 5 \mu 1 / \mu 1$ & 0.1 \\
\hline 10ng/ $\mu 1 \mathrm{DNA}$ & 2.0 \\
\hline \multirow[t]{2}{*}{$\mathrm{H}_{2} \mathrm{O}$} & 3.1 \\
\hline & $10 \mu \mathrm{L}$ \\
\hline
\end{tabular}

Table 2: PCR Condition

\begin{tabular}{lllllll}
\hline $\begin{array}{l}\text { Initial } \\
\text { density }\end{array}$ & Density & $\begin{array}{l}\text { Annealing } \\
\text { Temp. }\end{array}$ & Extension & $\begin{array}{l}\text { No. of } \\
\text { circles }\end{array}$ & $\begin{array}{l}\text { Final } \\
\text { Extension }\end{array}$ & $\begin{array}{l}\text { Hold } \\
\text { temp. }\end{array}$ \\
\hline $94^{\circ} \mathrm{C}$ & $94^{\circ} \mathrm{C}$ & $56^{\circ} \mathrm{C}$ & $72^{\circ} \mathrm{C}$ & 36 & $72^{\circ} \mathrm{C}$ & $10^{\circ} \mathrm{C}$ \\
$5 \mathrm{~min}$ & $30 \mathrm{sec}$ & $30 \mathrm{sec}$ & $45 \mathrm{sec}$ & & $7 \mathrm{~min}$ & $0 \mathrm{sec}$ \\
\hline \multicolumn{7}{c}{ Key: Temp- Temperature, No-Number, Min-Minute, Sec-Seconds }
\end{tabular}

Biosystems, Foster City, CA, USA by following

The amplicon from the reaction above was loaded on $1.5 \%$ agarose gel and the gel picture is attached as PCR. The ladder used is hyper ladder 1 from Bioloine. The expected base pair of the amplicon is around $850 \mathrm{bp}$. The PCR was purified with the above following protocol.

DNA Sequencing: The sequencing of the purified PCR products were done at Inqaba Biotechnology Industrial (Pty) Ltd, Pretoria, South Africa with PRISM $^{\mathrm{TM}}$ Ready Reaction Dye Terminator Cycle Sequencing Kit using the dideoxy chain termination method and electrophoresed with a model ABI PRISM® 350 XL DNA Sequencer (Applied manufacturer's instructions (Tiquia, 2010).

Sequence Analysis: ChromasLite version 2.33 software was used for the analysis of chromatograms, resulting from sequencing reaction for good quality sequence assurance.

The resulting chromatograms were edited using BioEdit sequence Alignment. After this, the resulting consensus 16S rDNA sequences obtained were blast in the NCBI database with the Basic Alignment Search Tool ( BLASTn) for homology in order to identify the probable organism in question. These sequences were deposited in the GenBank. 


\section{RESULTS AND DISCUSSION}

From the study, dominant digestive guts' microbiota was Cedeca davisae, Cronobacter dublinensis, Enterobacter aerogenes, Kluyvera cryocrescens, Klebsiella oxytoca, Providencia vermicola, Salmonella enteric, Providencia alcalifaciens, Serratia nematodiphila, Pseudomonas plecoqlossicida, Klebsiella michiganensis, Serratia marcenscens, Pseudomonas aeruginosa, Escherichia coli, Aeromonas hydrophila and Enterobacter asburiae. Klebsiella spp. was more abundant and prominent in the digestive guts of adult honeybees across all selected ecozones. The result of the percentage identity and closest accessionn of the isolates are presented in Table 3 Enterobacter aerogenes had the closest accession number on serial number 6.7. and 8 also recorded the highest percentage identity $(99 \%)$.

Table 3: Percentage identity and closest accession of isolates

\begin{tabular}{llll}
\hline Organisms & \multicolumn{2}{l}{ Percentage Closest } & S/N \\
& identity & accession & \\
\hline Asromonas hydrophila & $84 \%$ & KY938147.1 & 39 \\
Cedeca davisae & $88 \%$ & MF111213.1 & 3 \\
Cronobacter dublinensis & $84 \%$ & MK557935.1 & 4,5 \\
Enterobacter aerogenes & $99 \%$ & FJ976592.1 & $6,7,8$ \\
Enterobacter asburiae & $94 \%$ & MK577384.1 & 40 \\
Escherichia coli & $89 \%$ & MK621270.1 & $35-38$ \\
Klebsiella michiganensis & $97 \%$ & MG516135.1 & 19 \\
Klebsiella oxytoca & $98 \%$ & KP886828.1 & 11,16 \\
Kluyvera cryocrescens & $99 \%$ & MK047301.1 & 9,10 \\
Providencia aicalifaciens & $97 \%$ & MG754372.1 & 14,17 \\
Providencia vermicola & $91 \%$ & KJ833796.1 & 12 \\
Pseudomonas arruginosa & $93 \%$ & MK288113.1 & $27-34$ \\
Pseudomonas plecoglossicida & $95 \%$ & MK467545.1 & 18,20 \\
Salmonella enteric & $98 \%$ & LS483428.1 & 13 \\
Serratia marcenscens & $94 \%$ & LC041158.1 & $21-26$ \\
Serratia nematodiphila & $93 \%$ & MK447122.1 & 15 \\
\hline
\end{tabular}

Conclusion: The findings from this study showed that microbiota component community of A. mellifera adansonii in OOU was composed of more Gramnegative bacteria than Gram-positive bacteria in Odo Epo. Geographical locations dictate the abundance, occurrence and diversity of microbial communities and their interaction with honeybees. The study provides basic information for future genomic research aimed at understanding the evolutionary diversity and functional roles of microbiota community of honeybees and their economic benefit. Furthermore, this will enhance discovery and development of useful products of pharmaceutical importance and microbes for bio-remediation, biocontrol of pests of agricultural crops and pests of health importance.

\section{REFERENCES}

Baffoni, L; Gaggia, F; Alberoni, D; Cabbri, R; Nanetti, A; Biavati, B (2016). Effect of dietary supplementation of Bifidobacterium and Lactobacillus strains in Apis mellifera L. against Nosema ceranae. Beneficial microbes 7(1): 4551.

Engel, P; Kwong, WK; Frederick, MC (2016). The bee microbiome: impact on bee health and model for evolution and ecology of host-microbe interactions. Nature 7: 02164-02115

Guo, J; Wu, J; Chen, Y; Evans, JD; Dai, R; Luo, W; Li, J (2015). Characterization of gut bacteria at different developmental stages of Asian honey bees, Apis cerana. Journal of Invertebrate Pathology 127: 110-114

Li, J; Powell, JE; Guo, J; Evans, JD; Wu, J; Williams, P; Lin, Q; Moran, NA; Zhang, Z (2015). Two gut community enterotypes recur in diverse bumblebee species. Current Biology. 25: R652-R653

Muli, E; Patch, H; Frazier, M; Frazier, J; Torto, B; Baumgarten, T; Kilonzo, J; Kimani, J.N; Mumoki F; Masiga, D; Tumlinson, J; Grozinger, C (2014). Evaluation of the distribution and impacts of parasites, pathogens, and pesticides on honey bee (Apis mellifera) populations in East Africa. PLoS ONE, 9: 94459. 